\title{
Dopuszczenie do Komunii Świętej osób żyjących po małżeńsku bez małżeństwa - norma czy subiektywna ocena?
}

Problematyka możliwości pełnego udziału w Eucharystii wiernych, którzy żyją w związkach na sposób małżeński, jednakże bez ważnie zawartego małżeństwa kanonicznego, była przedmiotem wielu dyskusji i dokumentów Magisterium kościelnego. Kwestia ta jest także regulowana przez odpowiednie normy prawa kanonicznego oraz jest przedmiotem norm moralnych, które przecież stanowią integralną część dyscypliny Kościoła. Do momentu opublikowania adhortacji apostolskiej Amoris laetitia papieża Franciszka sprawa wyglądała na dość jasno uregulowaną. Co więcej, w miarę jednolita była też praktyka kościelna. Jeżeli ktoś nie stosował wypracowanych - zwłaszcza przez ostatnich papieży: św. Jana Pawła II i Benedykta XVI - zasad postępowania w takich sytuacjach, był uznawany za tego, kto narusza prawo i dyscyplinę kościelną. Wszystko zmieniło się pod wpływem niejasnych sformułowań zawartych w ósmym rozdziale wspomnianej adhortacji. Sformułowania te doprowadziły do powstania nie tylko różnych, ale wręcz przeciwstawnych interpretacji obowiązującej aktualnie dyscypliny Kościoła w tej materii. 
Przedmiotem niniejszej publikacji będzie analiza obowiązującego stanu prawnego regulującego kwestię pełnego uczestnictwa wiernych w sakramencie Eucharystii w świetle adhortacji apostolskiej Amoris laetitia papieża Franciszka. Pytanie badawcze brzmi: czy papież dokonał zmiany obowiązujących do tej pory kryteriów dopuszczenia do Komunii św. wiernych żyjących w związkach niesakramentalnych? A jeśli tak, to czy ta zmiana prowadzi do odrzucenia znaczenia norm obiektywnych na rzecz subiektywnego osądu?

Podejmując próbę znalezienia odpowiedzi na powyższe pytania, należy najpierw przedstawić aktualnie obowiązujący stan prawny oraz funkcjonującą do tej pory dyscyplinę kościelną w tym zakresie. Następnie należy wskazać na te fragmenty papieskiego dokumentu, które wzbudziły kontrowersje interpretacyjne, oraz przedstawić najbardziej znaczące reakcje na nie.

\section{Aktualny stan prawny i dyscyplinarny}

Kwestia norm kanonicznych regulujących przystępowanie wiernych do Komunii św. była w przeszłości po wielekroć omawiana przez wielu kanonistów ${ }^{1}$. Dlatego w tym miejscu zagadnienie

1 Odwołując się tylko do najnowszych tekstów, można wymienić: Z. Janczewski, Przyjmowanie Eucharystii przez osoby żyjące w matżeństwach niesakramentalnych, w: Reddite quae sunt Caesaris Caesari et quae sunt Dei Deo. Księga jubileuszowa dedykowana Księdzu Profesorowi Józefowi Krukowskiemu z okazji 5o-lecia pracy naukowej, red. M. Sitarz, P. Stanisz, H. Stawniak, Lublin 2014; U. Nowicka, Komunia dla rozwodników? Refleksje na kanwie wypowiedzi Prefekta Kongregacji Nauki Wiary z 23 października 2013 r., w: Reddite quae sunt Caesaris Caesari et quae sunt Dei Deo. Księga jubileuszowa dedykowana Księdzu Profesorowi Józefowi Krukowskiemu z okazji 5o-lecia pracy naukowej, red. M. Sitarz, P. Stanisz, H. Stawniak, Lublin 2014; W. Góralski, Sprawiedliwość czy mitosierdzie? Problem Komunii Świętej katolików rozwiedzionych i żyjących w małżeństwie cywilnym, Płock 2016; V. De Paolis, I divorziati risposati e i sacramenti dell'eucaristia e della penitenza, „Periodica” 103 (2014), s. 541-594; M. A. Ortiz, The Pastoral Care of Divorced and Civilly Remarried Members of the Faithful and Their Call to Holiness, w: Mercy and 
to zostanie przedstawione w sposób schematyczny, oddający istotę obowiązującej normatywy kanonicznej z uwzględnieniem pewnych trudności interpretacyjnych sygnalizowanych przez autorów.

Dyscyplina kanoniczna sakramentów świętych wynika wprost z doktryny Kościoła. Ma ona szczególne znaczenie nie tylko dla ustanowienia właściwego porządku ich sprawowania i przyjmowania, ale przede wszystkim dla zachowania istoty oraz tożsamości wspólnoty Kościoła i jego organizacji zgodnie z wolą Boskiego Założyciela. Ta dyscyplina opiera się o kilka założeń, które stanowią sam rdzeń doktryny katolickiej.

Po pierwsze należy zachowywać zawsze świadomość, że sakramenty Nowego Przymierza zostały ustanowione przez Jezusa Chrystusa i dane Kościołowi. Dlatego są takie same dla całego Kościoła i należą do depozytu wiary ${ }^{2}$. Z tego wynikają dwie bardzo ważne normy kanoniczne: najpierw ta, która stanowi, że więź sakramentalna jest jedną z trzech istotnych więzi i gwarancji pełnej wspólnoty Kościoła katolickiego tutaj na ziemi³; a następnie ta, która przesądza, że określanie wymogów do ważności celebracji sakramentów należy wyłącznie do kompetencji najwyższej władzy kościelnej, przy czym nawet ta władza nie może w sposób

Law in Marriage, ed. P. M. Dugan, L. Navarro, Montreal 2015, s. 87-142; W. Kowal, The Non-Admission of the Divorced and Remarried Persons to Holy Communion. Canon 915 Revisited, „Studia Canonica” 49 (2015), s. 411-441; J. Granados, Divorziati in nuova unione civile ed Eucaristia. La risposta della misericordia, „La Rivista del Clero Italiano” 96 (2015), s. 598-61o; Z. Janczewski, Udzielanie Komunii św. osobom rozwiedzionym? Analiza adhortacji „Amoris laetitia” papieża Franciszka, „Prawo Kanoniczne” 59 (2016) nr 2, s. 41-58.

2 Por. Sobór Trydencki, Dekret o sakramentach, w: DS 1600-1601; Katechizm Kościoła Katolickiego [dalej: КкK] 1114; Kodeks prawa kanonicznego [dalej: KPK 1983], kan. 841; Kodeks kanonów Kościołów wschodnich [dalej: KKKW], kan. 669.

3 Por. kan. 205 KРК 1983; kan. 8 KKKW.

4 Por. kan. 841 KPK 1983; kan. 669 KKKW. 
zupełnie dowolny zmieniać obrzędów sakramentalnych, ponieważ liturgia sakramentalna jest elementem konstytutywnym Tradycji Kościoła 5 .

Po drugie wierni mają prawo do tego, aby uzyskiwać pomoc w rozwoju własnego życia duchowego w dążeniu do świętości, zwłaszcza w postaci słowa Bożego i sakramentów ${ }^{6}$. Dlatego szafarze sakramentów mają obowiązek udzielenia ich każdemu wiernemu, który o nie właściwie prosi, jest odpowiednio przygotowany i prawo nie zabrania mu przyjęcia danego sakramentu7.

Po trzecie wśród siedmiu sakramentów Kościoła wyjątkowe miejsce zajmuje sakrament Eucharystii. Jest on najbardziej czcigodnym sakramentem, gdyż zostało w nim zawarte całe duchowe dobro Kościoła, którym jest sam Chrystus. Dlatego Eucharystia stanowi szczyt i źródło całego kultu oraz życia chrześcijańskiego. Częste przyjmowanie Komunii św. jest zalecane wiernym przez Kościół. Każdy wierny jest zobowiązany do jej przyjmowania przynajmniej raz w roku, najlepiej w okresie wielkanocnym, po przygotowaniu się przez sakrament pojednania i post ${ }^{8}$.

Przypomniane powyżej podstawowe zasady doktryny sakramentalnej Kościoła w sposób jednoznaczny przesądzają o tym, że sprawowanie i przyjmowanie sakramentów nie jest i nie może być pozostawione dowolnym decyzjom szafarzy, wiernych czy nawet wspólnoty kościelnej. Sakramenty święte, mając swoje źródło w woli Jezusa Chrystusa i będąc aktami ściśle eklezjalnymi, muszą bowiem podlegać - i w rzeczywistości podlegają - normom, które mają na celu ochronę ich tożsamości i świętości. Taki bowiem jest cel prawa kanonicznego, które po to istnieje w Kościele,

\footnotetext{
5 Por. KKК 1124-1125.

6 Por. kan. 213 KPK 1983; kan. 16 KKKW.

7 Por. kan. 843 § 1 KРK 1983.

8 Por. KкK 1389; kan. 897, 898, 912, 919 § 1, 920 § 1-2 КРК 1983; kan. 698, $699 \S 3,713 \S 2 \mathrm{KKKW}$.
} 
aby „wykonywanie funkcji powierzonych mu z nieba, zwłaszcza świętej władzy sprawowania sakramentów, było należycie uporządkowane" 9 .

Do tej konstatacji należy dodać kolejną. Normy prawa kanonicznego z chwilą ich promulgacji przez prawowitą władzę zaczynają obiektywnie istnieć i obowiązywać ich adresatów ${ }^{10}$. Normy prawne ze swej istoty mają charakter generalny i abstrakcyjny. Ich ukonkretnienie następuje w akcie stosowania prawa" .

Aplikując te zasady ogólne do prawa o sakramentach, należy stwierdzić, że udzielanie i przyjmowanie sakramentów, w tym także udzielanie i przyjmowanie Eucharystii, jest regulowane przez obiektywnie istniejące normy prawa kanonicznego. Wśród tych norm są takie, które mają szczególne znaczenie dla omawianej problematyki.

Pierwszą z nich jest norma stanowiąca prawo i zarazem obowiązek przyjmowania Komunii św. przez ochrzczonych ${ }^{12}$. Przyjmowanie Eucharystii ma szczególne znaczenie w niebezpieczeństwie śmierci oraz gdy jest ona udzielana na sposób wiatyku' ${ }^{13}$. Natomiast obowiązek przystąpienia do Komunii św. powinien być przez wiernych realizowany w okresach ustanowionych przez tradycję lub prawo partykularne Kościołów sui iuris, a zwłaszcza w okresie wielkanocnym ${ }^{14}$. Tak więc podstawową zasadą kanoniczną jest prawo wiernego do Eucharystii oraz obowiązek jej przyjmowania przynajmniej raz w roku, najlepiej w okresie wielkanocnym.

\footnotetext{
9 Jan Paweł II, Konstytucja apostolska Sacrae disciplinae leges (25.01.1983).

10 Por. kan. 7 i 12 KPK 1983; kan. 1488 i 1491 KKKW.

11 Por. R. Sobański, Nauki podstawowe prawa kanonicznego, t.1: Teoria prawa kanonicznego, Warszawa 2001, s. 69-76; 134-155.

12 Por. kan. 912 KPK 1983.

13 Por. kan. 921 i 922 KРК 1983; kan. 708 KкKW.

14 Por. kan. 920 KPK 1983; kan. 708 KKKW.
} 
Jednak prawo do przyjęcia Eucharystii nie jest bezwarunkowe. Prawo kanoniczne określa bowiem także warunki i okoliczności, które uniemożliwiają wiernemu przyjęcie Komunii św. Mają one charakter wykluczający. Jednocześnie normy te wyraźnie się od siebie różnią.

Pierwsza z tych norm zakazuje przystępować do Komunii Świętej tym wiernym, którzy mają świadomość pozostawania w grzechu ciężkim, bez odbycia uprzednio sakramentalnej spowiedzi. Zakaz ten nie obowiązuje w przypadku niemożliwości skorzystania z sakramentu pokuty i pojednania oraz pod warunkiem zaistnienia poważnej racji. W takim przypadku wymaga się jednak od wiernego zastosowania nadzwyczajnej formuły oczyszczenia duszy z grzechów ciężkich przez wzbudzenie aktu żalu doskonałego, który to akt zawiera już w sobie postanowienie wyspowiadania się przy pierwszej nadarzającej się okazji ${ }^{15}$. Norma ta pozostawia zatem decyzję o przystąpieniu do Komunii św. osądowi sumienia wiernego. Oznacza to, że wierny na podstawie obiektywnie istniejącej normy kanonicznej podejmuje autonomiczną, subiektywną decyzję w zakresie wewnętrznym (forum internum) o przystąpieniu bądź też nie do Komunii św. Warto przy tym podkreślić, że decyzja podjęta w sumieniu ma oczywiście swoje skutki w zakresie zewnętrznym, gdyż udział wiernych w Eucharystii jest co do zasady faktem publicznym. Nie sposób przy tym nie zauważyć, że to właśnie ta norma jest najczęściej stosowana przez wiernych, którzy świadomie nie przystępują do Komunii św. To jest po prostu powszechna praktyka w prawidłowo funkcjonującej wspólnocie. Jeśli mielibyśmy odpowiedzieć na pytanie, co jest główną przyczyną wykluczającą wiernych z pełnego uczestnictwa w sakramencie Eucharystii, to odpowiedź jest oczywista - osąd sumienia wiernego o stanie grzechu ciężkiego. I na odwrót - osąd sumienia o braku grzechu

15 Por. kan. 916 KРк 1983; kan. 711 KKKW. 
ciężkiego umożliwia wiernemu podjęcie decyzji o przyjęciu Eucharystii. Podsumowując, należy stwierdzić, że powszechna praktyka przyjmowania Eucharystii przez wiernych bazuje na obiektywnej normie kanonicznej, która upoważnia wiernego do podjęcia autonomicznej decyzji o przyjęciu Eucharystii w oparciu o osąd sumienia. Zatem nie ulega wątpliwości, że co do zasady o przystąpieniu do Komunii św. decydują w sposób autonomiczny poszczególni wierni, jednakże pod warunkiem braku innych prawnych zakazów.

Poza tą zasadniczą i powszechnie stosowaną normą w kościelnym porządku prawnym istnieje jeszcze inna zasada regulująca przyjmowanie Eucharystii przez wiernych. Jest ona zawarta odpowiednio w kan. 915 KPK 1983 i kan. 712 KKKW. Ponieważ przepisy tych dwóch kanonów różnią się nieco między sobą, warto w tym miejscu przytoczyć ich brzmienie. Kanon 915 KPK 1983 stanowi: „Do Komunii świętej nie należy dopuszczać ekskomunikowanych lub podlegających interdyktowi, po wymierzeniu lub deklaracji kary, jak również innych osób trwających z uporem w jawnym grzechu ciężkim”. Natomiast formuła kan. $712 \mathrm{KKKW}$ jest bardziej lakoniczna i brzmi: „Przyjęcie Boskiej Eucharystii jest zabronione tym, którzy są publicznie znani jako niegodni”.

Pomimo odmiennych sformułowań kodeksowych można z łatwością określić charakter tej normy. Jest to norma zakazująca określonej kategorii wiernych przyjmowania Eucharystii. Nie może ona jednak być postrzegana jako coś wyjątkowego w kościelnym porządku prawnym, ponieważ ten porządek przewiduje możliwość prawnego zakazu przyjmowania sakramentów, jak o tym była mowa powyżej. Jednocześnie należy wskazać na wyraźną różnicę w stosunku do normy zawartej w kan. 916 KPK 1983 i kan. 711 KK KW. W przypadku omawianej normy kan. 915 KPK 1983 i kan. 712 KK KW źródłem zakazu przyjęcia Komunii św. nie jest subiektywna i autonomiczna decyzja wiernego oparta o osąd sumienia, lecz stwierdzenie obiektywnie istniejącego stanu faktycznego. 
Tym, co rodzi trudności w interpretacji omawianej normy, jest ogólność sformułowań, które mają wyznaczać desygnaty normy. Kim bowiem są ci, którzy „trwają z uporem w jawnym grzechu ciężkim” czy też są „publicznie znani jako niegodni”? Odnosząc te pytania do omawianej w tej publikacji problematyki, można to pytanie sformułować jeszcze inaczej: czy wierni żyjący po małżeńsku (uxoris modo), ale bez zawarcia małżeństwa kanonicznie ważnego, są objęci zakazem tej normy?

Problem ten został już zauważony w pracach nad reformą kodeksu łacińskiego; dlatego też komisja pracująca nad tekstem obecnego kan. 915 KPK 1983 wyraźnie stwierdziła, że norma ta dotyczy z całą pewnością rozwiedzionych i żyjących w nowych związkach ${ }^{16}$, a ewentualna zmiana tej dyscypliny kościelnej, postulowana w głosach niektórych kanonistów i teologów, mogłaby zostać dokonana tylko i wyłącznie przez Stolicę Apostolską. Nie można tego problemu rozstrzygnąć na poziomie komisji ${ }^{17}$.

Być może to sformułowanie spowodowało, że sprawa nie została uznana za ostatecznie przesądzoną i nadal istnieje możliwość poszukiwania takich rozwiązań, które chociażby części wiernych dotkniętych tym zakazem pozwoliłyby na pełny udział w Eucharystii.

16 „Textus sufficit cum omnia requisita habeantur: actus gravitas, nempe, et publicitas actus necnon contumacia. Certocertius textus respicit etiam divortiatos et renuptiatos". Pontificia Commissio Codici Iuris Canonici Recognoscendo, Relatio complectens synthesim animadversionum ab Em.mis atque Exc.mis Patribus Commissionis ad novissimum schema Codicis Iuris Canonici exhibitarum, cum responsionibus a Secreteria et Consultoribus datis, E Civitate Vaticana 1981, s. 214; „Communicationes" 15 (1983) nr 2, s. 194; por. J. Manzanares, Eucaristia, w: Il Codice del Vaticano II. I sacramenti della chiesa, ed. A. Longhitano, Bologna 1989, s. 100-101.

17 "Nonnuli in animadversionibus petierunt ut hoc in loco textus exhibeatur qui provideat possibilitatem adeundi ad sacram Communionem pro fidelibus divortiatis et denuo coniugatis. - Omnes consultores concordat Commissionis non esse istis decernere: erit Sanctae Sedis quaestioni respondere” - „Communicationes” $13(1981)$ nr 2, s. 412. 
Dlatego też od ponad trzydziestu lat toczy się w Kościele poważna dyskusja na ten temat. W tej dyskusji biorą udział nie tylko teologowie i kanoniści, ale również miały i mają miejsce interwencje Nauczycielskiego Urzędu Kościoła ${ }^{18}$.

Dotychczasową dyscyplinę Kościoła w zakresie dopuszczania do Komunii św. wiernych, którzy żyją w związkach nieważnych kanonicznie, można streścić w następujący sposób:

1) Zgodnie z doktryną i stałą praktyką Kościoła osoby rozwiedzione i żyjące w nowych związkach co do zasady nie mogą być dopuszczone do Komunii eucharystycznej ze względu na to, iż żyją w obiektywnym stanie jawnego grzechu ciężkiego.

2) Dopuszczenie do Komunii św. tychże osób, chociaż należy traktować to jako wyjątek od zasady, jest możliwe po spełnieniu określonych warunków, do których należą: uznanie winy i żal za złamanie przymierza małżeńskiego i wierności, nieodwracalność sytuacji nowego związku, realizacja ważnego dobra, zobowiązanie się do zachowania wstrzemięźliwości oraz odsunięcie niebezpieczeństwa zgorszenia.

3) Akt dopuszczenia do Komunii św. dokonuje się poprzez uzyskanie pojednania w sakramencie pokuty, a więc jest aktem ipso facto z zakresu wewnętrznego.

4) Akt zobowiązania się do zachowania wstrzemięźliwości może zostać podjęty w zakresie wewnętrznym i poddany pod osąd spowiednika, który posiada władzę oceniania, czy penitent posiada dyspozycję do otrzymania rozgrzeszenia (kan. 978 § 1 i 2 KPK 1983; kan. 980 KPK 1983; kan. 732 § 1 KKKW) ${ }^{19}$.

18 Bardzo dobre streszczenie tej debaty znajdujemy w: W. Góralski, Sprawiedliwość czy miłosierdzie..., dz. cyt., s. 8-54.

19 Szerzej na ten temat pisze P. Steczkowski, Dopuszczenie rozwiedzionych $i$ żyjących w nowych zwiq̨zkach do komunii świętej. Forum externum czy forum internum, „Annales Canonici” 4 (2008), s. 83-97. 
W tym miejscu koniecznie należy podkreślić, że w doktrynie Kościoła za rzecz oczywistą przyjmuje się to, że zakaz przyjmowania Komunii św. obejmuje w sposób bezwzględny tych wiernych, którzy podejmują życie na sposób małżeński bez ważnego małżeństwa w sytuacji, gdy nie istnieją żadne przeszkody kanoniczne do jego zawarcia.

\section{Synod Biskupów i adhortacja apostolska Amoris laetitia}

Nowym impulsem do podjęcia tematu udzielania Komunii św. wiernym żyjącym na sposób małżeński bez ważnego kanonicznie małżeństwa i do refleksji nad aktualnie obowiązującą dyscypliną Kościoła w tym zakresie stało się zwołanie przez papieża Franciszka Zgromadzenia Ogólnego Synodu Biskupów na temat powołania i misji rodziny w Kościele i świecie współczesnym, które pracowało dwuetapowo - w 2014 i w 2015 roku. Pierwszą poważną oznaką tego, że problematyka znów powraca do wewnętrznej dyskusji Kościoła, było wystąpienie niemieckiego kardynała Waltera Kaspera podczas nadzwyczajnego konsystorza kardynałów, który odbywał się w dniach 20-21 lutego 2014 roku w Rzymie. Ów bardzo ceniony (także przez papieża Franciszka) teolog wyraził wówczas opinię, że wierni, którzy po rozpadzie ważnego małżeństwa żyją w nowych związkach, ale wyrażają szczery żal z powodu rozpadu swojego małżeństwa, uregulowali swoje naturalne obowiązki z niego wynikające, definitywnie wykluczyli powrót do tego związku, usiłują żyć w tym drugim związku możliwie jak najlepiej, zachowywać wiarę i wychowywać w niej potomstwo oraz wyrażają pragnienie przyjmowania sakramentów jako źródła siły duchowej, mogliby po okresie pokuty i refleksji przystąpić do sakramentu pokuty i pojednania, otrzymać rozgrzeszenie i odzyskać prawo do przyjmowania Eucharystii. Uzasadniając tę opinię, kardynał Kasper odwoływał się do dawnej praktyki pokutnej, którą Kościół 
stosował wobec tzw. upadłych, czyli tych, którzy porzucili wiarę katolicką, a następnie wyrazili pragnienie powrotu do Kościoła. Jednocześnie niemiecki kardynał wyraźnie zastrzegł, że każda sytuacja winna być rozpatrywana indywidualnie, aby nie pogorszyć duchowego stanu wiernych ${ }^{20}$.

Następnym etapem tej dyskusji były obrady Nadzwyczajnego Zgromadzenia Ogólnego Synodu Biskupów w dniach 5-19 października 2014 roku. W tym gremium ujawniły się dwa odmienne stanowiska. Jedna grupa biskupów opowiadała się za utrzymaniem dotychczas obowiązującej dyscypliny kościelnej, akcentując to, że bardzo dobrze wyraża ona i zarazem chroni zasadę nierozerwalności małżeństwa. Natomiast inni biskupi opowiedzieli się za propozycją sformułowaną przez kardynała Kaspera. Te dwa stanowiska znalazły swój wyraz w dokumencie końcowym synodu ${ }^{21}$.

Dyskusję na ten temat kontynuowano podczas XIV Zwyczajnego Zgromadzenia Ogólnego Synodu Biskupów, które miało miejsce w dniach 4-25 października 2015 roku. Efekty tej dyskusji zostały zawarte $\mathrm{w}$ dokumencie końcowym synodu, który został przekazany papieżowi Franciszkowi jako materiał do przygotowania posynodalnej adhortacji apostolskiej. W dokumencie tym biskupi wskazują na konieczność otoczenia opieką duszpasterską wiernych żyjących w związkach, które nie są małżeństwami ważnymi kanonicznie, oraz wskazują na potrzebę ich lepszej integracji ze wspólnotą kościelną. Dokument podkreśla znaczenie towarzyszenia i rozeznania duszpasterskiego, które ma pomóc tym wiernym przez rozmowę z kapłanem prowadzoną na forum internum, rozpoznać w sumieniu ich faktyczną sytuację przed Bogiem i określić, w jaki sposób mogliby oni pełniej uczestniczyć

\footnotetext{
20 Por. W. Góralski, Sprawiedliwość czy miłosierdzie..., dz. cyt., s. 14-15.

21 Por. III Nadzwyczajne Zgromadzenie Ogólne Synodu Biskupów, Relatio Synodi, 18.10.2014, n. 52 .
} 
w życiu Kościoła. Zwrócono też w nim uwagę na zróżnicowanie oceny moralnej w odniesieniu do tych wiernych ${ }^{22}$.

Nie ulega wątpliwości, że obydwa dokumenty synodalne stały się podstawą dla adhortacji apostolskiej Amoris laetitia papieża Franciszka, która została ogłoszona w dniu 19 marca 2016 roku $^{23}$. Stąd też w tekście adhortacji została poruszona przez ojca św. problematyka dopuszczania do Komunii św. wiernych żyjących w tzw. sytuacjach nieregularnych.

Przede wszystkim papież Franciszek konstatuje, że:

(...) biorąc pod uwagę niezliczoną różnorodność poszczególnych sytuacji (...) można zrozumieć, że nie należy oczekiwać od Synodu ani też od tej adhortacji nowych norm ogólnych typu kanonicznego, które można by stosować do wszystkich przypadków. Możliwa jest tylko nowa zachęta do odpowiedzialnego rozeznania osobistego i duszpasterskiego indywidualnych przypadków, które powinno uznać, że ponieważ stopień odpowiedzialności nie jest równy w każdym przypadku, to konsekwencje lub skutki danej normy niekoniecznie muszą być takie same $(. . .)^{24}$.

W tym miejscu następuje przypis 336, w którym papież dopowiada:

Nawet, gdy chodzi o dyscyplinę sakramentalną, ponieważ po rozeznaniu można uznać, że w danej sytuacji nie ma poważnej winy. Stosuje się tutaj to, co powiedziałem w innym dokumencie.

22 Por. XIV Zwyczajne Zgromadzenie Ogólne Synodu Biskupów, Relazione finale del Sinodo dei Vescovi al Santo Padre Francesco, 24.10.2015, n. 84-86.

23 W sposób bardzo precyzyjny wykazał to ks. prof. Wojciech Góralski, wskazując, że dokument papieski zawiera pięćdziesiąt dwie cytacje z Relatio Synodi z roku 2014 i aż osiemdziesiąt cztery z Relatio finalis z roku 2015. Por. W. Góralski, Adhortacja apostolska Amoris laetitia papieża Franciszka. Prezentacja dokumentu z komentarzem do nn. 300-308, Płock 2016, s. 6.

24 Franciszek, Adhortacja apostolska Amoris laetitia [dalej: AL], 19.03.2016, n. 300. 
Po czym papież Franciszek powołuje się na tekst swojej pierwszej adhortacji apostolskiej Evangelii gaudium, a konkretnie na n. 44 i 47 tego dokumentu. Warto zatem przytoczyć te fragmenty:

(...) zarówno Pasterze, jak i wszyscy wierni towarzyszący swoim braciom w wierze lub na drodze otwierania się na Boga, nie mogą zapominać o tym, czego z taką jasnością naucza Katechizm Kościoła Katolickiego: „Poczytalność i odpowiedzialność za jakieś działania mogą zostać zmniejszone, a nawet zniesione, na skutek niewiedzy, nieuwagi, przymusu, strachu, przyzwyczajeń, nieopanowanych uczuć oraz innych przyczyn psychicznych lub społecznych". Dlatego też, nie pomniejszając wartości ewangelicznego ideału, należy z miłosierdziem i cierpliwością towarzyszyć możliwym etapom wzrastania osób formujących się dzień po dniü ${ }^{25}$.

A także:

Wszyscy mogą należeć do wspólnoty i nawet drzwi sakramentów nie powinno się zamykać z byle jakich powodów. Odnosi się to przede wszystkim do sytuacji, w której chodzi o ten sakrament, który jest bramą - o chrzest. Eucharystia, chociaż stanowi pełnię życia sakramentalnego, nie jest nagrodą dla doskonałych, lecz szlachetnym lekarstwem i pokarmem dla słabych. Przekonania te mają również konsekwencje duszpasterskie, nad którymi powinniśmy się zastanowić z roztropnością i odwagą. Często zachowujemy się jak kontrolerzy łaski, a nie jak ułatwiający. Kościół jednak nie jest urzędem celnym, jest ojcowskim domem, gdzie jest miejsce dla każdego $\mathrm{z}$ jego niełatwym życiem ${ }^{26}$.

25 Franciszek, Adhortacja apostolska Evangelii gaudium [dalej: EvG], 24.11.2013, n. 44 . 26 EvG, n. 47. 
Ponadto ważne treści dla omawianej tu problematyki zostały zawarte w dwóch innych miejscach papieskiego dokumentu. I tak w AL, n. 304 czytamy:

Byłoby czymś małostkowym zatrzymywanie się, by rozważać jedynie, czy działanie danej osoby odpowiada czy też nie jakiemuś prawu, czy normie ogólnej, bo to nie wystarcza, by rozeznać i zapewnić pełną wierność Bogu w konkretnym życiu ludzkiej istoty. Gorąco proszę, abyśmy pamiętali o tym, czego uczy św. Tomasz z Akwinu i abyśmy uczyli się przyswajać to w rozeznaniu duszpasterskim: „Chociaż w ogólnych zasadach istnieje jakaś konieczność, to jednak im bardziej schodzi do szczegółów, tym łatwiej o uchybienia. Natomiast w dziedzinie postępowania nie we wszystkich jest ta sama prawda lub poprawność działania, gdy chodzi o szczegóły, a tylko gdy chodzi o konkretne zasady (...)”.

A następnie papież konkluduje:

To prawda, że normy ogólne stanowią pewne dobro, którego nigdy nie powinno się ignorować lub zaniedbywać, ale w swoich sformułowaniach nie mogą obejmować absolutnie wszystkich szczególnych sytuacji.

Natomiast w kolejnym punkcie adhortacji Franciszek stwierdza:

Ze względu na uwarunkowania i czynniki lagodzące możliwe jest, że pośród pewnej obiektywnej sytuacji grzechu osoba, która nie jest subiektywnie winna albo nie jest w pełni winna, może żyć w łasce Bożej, może kochać, a także może wzrastać w życiu łaski i miłości, otrzymując w tym celu pomoc Kościoła.

I w następującym w tym miejscu przypisie 351 dodaje: „W pewnych przypadkach mogłaby to być również pomoc sakramentów". Przywołane powyżej fragmenty adhortacji mogą budzić wątpliwości co do tego, czy jednak nie następuje istotna zmiana 
w obowiązującej dotychczas doktrynie i dyscyplinie Kościoła, regulującej możliwość i zasady udzielania Komunii św. wiernym żyjącym na sposób małżeński bez ważnego małżeństwa. Przejawem tych wątpliwości były sprzeczne ze sobą wypowiedzi ważnych przedstawicieli Stolicy Apostolskiej oraz różniące się znacznie od siebie dyrektywy dyscyplinarne wydawane przez poszczególne konferencje biskupów.

Istota powstałych wątpliwości została sformułowana i wyrażona w liście napisanym przez czterech kardynałów, skierowanym bezpośrednio do papieża Franciszka oraz przekazanym do wiadomości kardynała Gerharda Ludwiga Müllera, prefekta Kongregacji Nauki Wiary.

\section{List czterech kardynałów}

W dniu 19 września 2016 roku czterech kardynałów skierowało list do papieża Franciszka. Byli to kardynałowie: Walter Brandmüller, Raymond L. Burke, Carlo Caffarra oraz Joachim Meisner. W swoim liście, powołując się na liczne głosy biskupów i kapłanów dochodzące do nich z różnych stron świata, zwrócili się z prośbą o to, aby papież Franciszek podjął interwencję i rozwiał w sposób jednoznaczny poważne wątpliwości, które wynikają z treści rozdziału ósmego adhortacji apostolskiej Amoris laetitia, a które wprowadzają zamęt w życie wielu wiernych. Ponieważ kardynałowie nie otrzymali żadnej odpowiedzi ze Stolicy Apostolskiej, zdecydowali się upublicznić ten list w środkach społecznego przekazu, co nastąpiło w dniu 14 listopada $2016 \mathrm{roku}^{27}$.

Wątpliwości, które zostały sformułowane w liście czterech kardynałów, są następujące:

27 Por. S. Magister, Fare chiarezza. Nodi irrisolti di Amoris laetitia. Un appello, http://chiesa.espresso.repubblica.it/articolo/1351414.html (15.11.2016). 
1) Czy osobom żyjącym more uxorio można udzielać sakramentu pojednaniaiw ten sposóbdopuścićich doEucharystii bez konieczności spełnienia warunków sformułowanych w adhortacji apostolskiej Familiaris consortio, n. 84, w encyklice Reconciliatio et poenitentia, n. 34 oraz w adhortacji apostolskiej Sacramentum caritatis, n. 29?

2) Czy wyrażenie „w pewnych przypadkach” zawarte w przypisie 351 znajdującym się w adhortacji apostolskiej Amoris laetitia, n. 305 może być odniesione do osób rozwiedzionych, żyjących w nowych związkach na sposób małżeński?

3) Czy nadal obowiązuje nauczanie z encykliki Veritatis splendor, n. 79, oparte na Piśmie św. i Tradycji Kościoła, o istnieniu norm moralnych absolutnych, obowiązujących bez wyjątków, które zakazują aktów wewnętrznie złych?

4) Czy osoba, która w stały sposób żyje w sytuacji sprzecznej z przykazaniem prawa Bożego zakazującym np. cudzołóstwa, znajduje się w obiektywnej sytuacji grzechu ciężkiego, czemu zdaje się przeczyć treść Amoris laetitia, n. 301?

5) Czy obowiązuje nadal nauczanie z encykliki Veritatis splendor, n. 81, bazujące na Piśmie św. i Tradycji Kościoła, mówiące o tym, że okoliczności lub intencje nie mogą nigdy przekształcić aktu wewnętrznie niegodziwego ze względu na swój przedmiot w akt subiektywnie godziwy i możliwy do wyboru, co zdaje się sugerować treść Amoris laetitia, n. 302?

6) Czy biorąc pod uwagę treść Amoris laetitia, n. 303, nadal obowiązuje nauczanie z encykliki Veritatis splendor, n. 56, bazujące na Piśmie św. i Tradycji Kościoła, które wyklucza możliwość dokonywania przez ludzkie sumienie interpretacji kreatywnej i potwierdza, że sumienie nie jest upoważnione do usprawiedliwienia wyjątków od norm moralnych, które zakazują aktów wewnętrznie złych ze względu na ich przedmiot?28

28 Por. S. Magister, Fare chiarezza... 
Warto dodać, że kardynałowie nie ograniczyli się jedynie do przedstawienia tak sformułowanych wątpliwości. Każda z nich została przez nich dokładnie omówiona i pogłębiona z uwypukleniem dwuznaczności, które kryją się za poddanymi krytyce sformułowaniami adhortacji papieża Franciszka. Zarówno treść wątpliwości, jak też ich uzasadnienie oraz autorytet naukowy i kościelny autorów upoważniają do stwierdzenia, że Amoris laetitia nie przedstawia w sposób jasny doktryny Kościoła. Tym samym rodzi się w pełni uzasadniona wątpliwość co do aktualnej dyscypliny Kościoła w omawianym zakresie.

Dla omawianej tutaj tematyki szczególne znaczenie ma wątpliwość piąta. Otóż kardynałowie domagają się od papieża Franciszka wyjaśnienia, czy aby w tekście adhortacji nie przypisuje on ludzkiemu sumieniu funkcji kreatywnej. Pod tym pojęciem kryje się uznanie, że ostatecznym kryterium orzekania o dobru i złu moralnym jest głos sumienia. Oznacza to, że sumienie nie osądza decyzji ludzkiej w świetle obiektywnych norm prawa moralnego, ale samo może takie normy kreować. O skutkach przyjęcia takiej koncepcji sumienia pisał św. Jan Paweł II w encyklice Veritatis splendor tak:

Ujęcie to, uwzględniając okoliczności i sytuację, mogłoby dostarczać uzasadnień do wyjątków od reguły ogólnej i tym samym pozwalaćw praktyce na dokonywanie z czystym sumieniem czynów, które prawo moralne uznaje za wewnętrznie złe. $\mathrm{W}$ ten sposób wprowadza się w niektórych przypadkach rozdział lub nawet opozycję między doktryną wyrażoną przez nakaz o charakterze ogólnym a normą indywidualnego sumienia, które miałoby w praktyce stanowić ostateczną instancję orzekającą o dobru i złu. Na tej podstawie próbuje się uzasadnić tak zwane rozwiązania pastoralne, sprzeczne z nauczaniem Magisterium i usprawiedliwić twórczą hermeneutykę, według której poszczególna norma negatywna bynajmniej nie we wszystkich przypadkach jest wiążąca dla sumienia ${ }^{29}$.

29 Jan Paweł II, Encyklika Veritatis splendor, 6.o8.1993, n. 56. 
Kardynałowie, ilustrując w konkretny sposób, do czego mogłoby doprowadzić zaprzeczenie nauce zawartej w encyklice Veritatis splendor, piszą, że w takim przypadku mogłoby dojść do sytuacji, w której sumienie uznawałoby, że wola Boża objawia się także w czynach, które naruszają Jego przykazania. Na przykład przykazanie „nie cudzołóż” byłoby postrzegane zaledwie jako pewna norma ogólna. Natomiast w konkretnym przypadku, uwzględniając dobre intencje osoby i stosowne okoliczności, można by się cudzołóstwa dopuścić jako czynu, którego tu i teraz domaga się Bóg. Ale to oznaczałoby, że sumienie ludzkie w ostateczności decyduje o kryterium dobra i zła moralnego. Natomiast prawo Boże zostałoby zdegradowane do zbędnego ciężaru nakładanego na człowieka i przeszkadzającego mu w osiągnięciu pełni szczęścia ${ }^{30}$.

Moim zdaniem rozstrzygnięcie tej wątpliwości jest decydujące dla udzielenia odpowiedzi na kluczowe pytanie, czy nastąpiła zmiana w dyscyplinie Kościoła w materii dopuszczania do Komunii św. wiernych znajdujących się w tzw. nieregularnych sytuacjach małżeńskich. Jeżeli bowiem dopuści się funkcję kreatywną ludzkiego sumienia, które w ten sposób stanie się ostateczną miarą dobra i zła moralnego oraz praw i obowiązków wiążących wiernego w konkretnym przypadku, to jest oczywiste, że sprawa przyjmowania Komunii św. będzie zawsze kwestią tylko i wyłącznie subiektywnej decyzji wiernego. Przyjęcie takiej wykładni odnośnie funkcji sumienia jest wystarczające do tego, aby zmienić dyscyplinę Kościoła, nie zmieniając norm kanonicznych. Oznacza to bowiem, że aktualnie obowiązujące normy kan. 915 i 916 KPK 1983 oraz odpowiednio kan. 711 i 712 KKKW mogłyby być aplikowane w sposób absolutnie dowolny, tzn. bez odniesienia do Bożego prawa moralnego. Byłaby to sytuacja zupełnie inna

30 Por. Lettera di quattro cardinali al papa Francesco, http://chiesa.espresso.repubblica.it/articolo/1351414.html (15.11.2016). 
od aktualnej. Obecnie bowiem jest faktem, że wierny, podejmując decyzję o przystąpieniu do Komunii św., decyduje o tym we własnym sumieniu, ale chodzi tu o osąd sumienia jako konfrontację konkretnego czynu dokonanego w konkretnych okolicznościach z normą prawa moralnego. Podobnie szafarz Komunii św., który nie dopuszcza wiernego do jej przyjęcia, podejmuje decyzję we własnym sumieniu, ale konfrontując je $\mathrm{z}$ obiektywnym stanem niegodności tego wiernego wywołanym przez jawne, wyraźne i poważne przekroczenie norm prawa Bożego i naruszenie w ten sposób „spójności eucharystycznej”, która jest obiektywnym obowiązkiem każdego wiernego ${ }^{31}$. Jeżeli szafarz nie dokonałby konfrontacji z obiektywną normą i stanem faktycznym, a nie dopuściłby wiernego do Komunii św., tym samym byłby winien nadużycia swoich uprawnień i uniemożliwienia korzystania przez wiernego z przysługujących mu praw. Tak więc istnienie obiektywnych norm prawnych i moralnych tworzy konieczny porządek we wspólnocie kościelnej i chroni przed arbitralnymi decyzjami, które mogłyby godzić w dobro duchowe wiernych.

\section{Uwagi podsumowujące}

Ponieważ dotychczas brak jest odpowiedzi ze strony Stolicy Apostolskiej na przedstawione papieżowi Franciszkowi przez czterech kardynałów wątpliwości, a z dostępnych enuncjacji prasowych wynika, że nie należy się spodziewać takiej reakcji w przewidywalnej przyszłości, zachodzi konieczność podjęcia próby interpretacji interesujących nas fragmentów adhortacji i wyciągnięcia ostatecznych wniosków. Na bazie dotychczasowych rozważań można poczynić kilka istotnych uwag.

31 Por. Benedykt XVI, Adhortacja apostolska Sacramentum caritatis, 22.02.2007, n. 84 . 
Te końcowe rozważania należy rozpocząć od tego, że papież Franciszek kładzie nacisk na konieczność przeprowadzenia procesu rozeznania, którego celem jest ustalenie faktycznej moralnej sytuacji wiernego. Chodzi o zbadanie, jaka jest jego rzeczywista wina subiektywna $\mathrm{w}$ momencie znalezienia się w obiektywnej sytuacji grzechu. Ponieważ takie rozeznanie nie jest łatwe, stąd zobowiązanie dla spowiedników i kierowników duchowych, aby towarzyszyli wiernym w tym procesie i służyli im pomocą ${ }^{32}$.

Przedmiotem tego rozeznania jest aplikacja norm prawa moralnego i kanonicznego do konkretnego wiernego. Jest oczywiste, że wszelkie normy prawa, w tym także prawa Bożego, mają charakter ogólny i abstrakcyjny w tym sensie, że zakładają określoną hipotetyczną sytuację. Normy jako wzorce pożądanych zachowań spełniają swoje zadanie w momencie ich aplikacji. Należy zatem dokonać istotnego rozróżnienia pomiędzy tworzeniem normy a jej realizacją. Aplikacja norm musi uwzględniać konkretną sytuację podmiotu, coś, co papież Franciszek określa mianem okoliczności. Akt rozeznania, o którym jest mowa w adhortacji, powinien być $\mathrm{w}$ moim przekonaniu czynnością polegającą na rozpoznaniu okoliczności, w których dana osoba aplikowała normę. Jest to konieczne dla prawidłowej oceny odpowiedzialności człowieka. Należy przy tym pamiętać o zasadzie słuszności kanonicznej, która nakazuje stosować prawo kanoniczne z uwzględnieniem jego ostatecznej racji, tzn. zbawienia dusz. Problem, który pojawia się w tym momencie, polega na tym, że norma o zakazie cudzołóstwa jest pochodzenia Bożego. Pytanie brzmi: czy człowiek może pozostawać w błędzie co do tego rodzaju normy? Oczywiście jest to możliwe; ale wówczas zadaniem rozeznania 
powinno być ukształtowanie prawdziwego, a nie błędnego osądu sumienia.

Charakter rozeznania duszpasterskiego musi uwzględniać prawny wymiar sakramentów Kościoła. Wynika on przynajmniej z dwóch racji. Po pierwsze z samej natury sakramentów jako widzialnych znaków, a więc czynności, które wywołują określone skutki, zmieniając np. status prawny osoby ${ }^{33}$. Po drugie sakramenty mają wymiar eklezjalny, a to oznacza, że nie mogą być „prywatyzowane”. Są one czynnościami Chrystusa i Kościoła. Zawierają w sobie obiektywizm pochodzący od samego Chrystusa, który je ustanowił. To właśnie powoduje, że Kościół nie może pozwolić na to, aby nie było w ogóle obiektywnej, tzn. uregulowanej prawnie, dyscypliny sakramentalnej. Byłoby to sprzeczne z naturą sakramentów, z rozumieniem wspólnoty oraz z Tradycją, która tworzyła się wokół sakramentów. Dlatego też kwestia udziału wiernych w życiu sakramentalnym, w tym także ich pełnego uczestnictwa w Eucharystii, musi pozostać kwestią normy, a nie subiektywnej oceny. Akty sakramentalne są aktami wspólnoty i muszą podlegać kontroli z jej strony.

Stąd też znacząca rola biskupów i kapłanów jako świętych szafarzy w zachowaniu dyscypliny sakramentalnej. Ostatecznie to szafarz decyduje o niedopuszczeniu wiernego do Komunii św. Problem polega na tym, że prawo ma chronić wiernych przed decyzjami arbitralnymi. W związku z tym istnieje potrzeba sformułowania jasnych kryteriów podejmowania takich decyzji. Te kryteria zostały sformułowane w odniesieniu do osób żyjących w sytuacjach nieregularnych przez Jana Pawła II w adhortacji apostolskiej Familiaris consortio. Wydaje się, że papież Franciszek w Amoris laetitia położył nacisk nie na precyzję

33 O jurydycznym wymiarze sakramentów traktuje monografia: E. Besson, La dimension juridique des sacraments, Roma 2004. 
obiektywnych przesłanek i warunków dopuszczenia do Komunii św. takich osób, ale na osąd duszpasterza jako ich kierownika duchowego.

W tej sytuacji powstaje pytanie: czy sumienie duszpasterza może stać się ostatecznym kryterium dopuszczenia wiernych do Komunii św.? Według Amoris laetitia wydaje się, że odpowiedź jest twierdząca. Taka odpowiedź jest do zaakceptowania na gruncie dotychczas obowiązujących norm, ale należałoby w sposób bardzo jasny dodać warunek konieczny, a mianowicie że sumienie to nie tworzy nowej normy moralnej, lecz aplikuje istniejącą.

Oczywiście rezygnacja z jasno sformułowanych kryteriów na rzecz sumienia duszpasterza ma swoje blaski i cienie. Pozytywnym aspektem całej sprawy jest niewątpliwie to, że osoba poddająca się takiemu kierownictwu ma pewność, że jej przypadek jest potraktowany w sposób bardzo indywidualny, że rozpoznanie okoliczności aplikacji normy jest jednostkowe oraz że Kościół nie pozostawia jej samej w trudnej sytuacji, ale stara się jej towarzyszyć. Natomiast aspektem negatywnym jest to, że wielość możliwych rozwiązań może prowadzić do relatywizacji normy moralnej w odbiorze wiernych.

Zatem powierzenie decyzji o dopuszczeniu bądź niedopuszczeniu do Komunii św. duszpasterzowi nie jest ani nowością, ani jakimś odejściem od zasad kanonicznych. Problemem głównym jest sugestia ze strony papieża, że wejście w sytuację pożycia na sposób małżeński bez ważnego kanonicznie małżeństwa może w niektórych okolicznościach odbywać się bez winy moralnej osoby podejmującej taką decyzję. Jednak - jak zauważają kardynałowie w swoim liście - bardzo trudno jest sobie wyobrazić taką sytuację w praktyce ${ }^{34}$. Zauważmy, że nie chodzi tutaj o brak winy moral-

34 Por. Lettera di quattro cardinali... 
nej przy rozpadzie pierwszego małżeństwa, gdyż takie sytuacje są dosyć częste, lecz o decyzję wejścia w sytuację nieregularną. Nawet jeśliby przyjąć, że istniały okoliczności wyłączające lub ograniczające odpowiedzialność moralną w momencie podejmowania takiej decyzji (np. sytuacja błędu co do faktycznej śmierci małżonka), to jednak utrzymanie tego stanu przez cały czas trwania związku wydaje się nieprawdopodobne. Co więcej, zadaniem duszpasterza powinno być uświadomienie osobie powagi sytuacji i ogłoszenie prawdy o jej stanie moralnym. Natomiast moim zdaniem nie jest uprawnione przekonanie, że jeżeli osoba weszła w sytuację nieregularną bez własnej poważnej winy, to już sam ten fakt zwalnia ją z wszelkiej odpowiedzialności moralnej i otwiera drzwi do sakramentalnego życia we wspólnocie Kościoła.

Biorąc pod uwagę całość powyższych rozważań oraz sam tekst adhortacji papieża Franciszka, można sformułować następujące wnioski:

1) Papież Franciszek w żadnym punkcie adhortacji apostolskiej Amoris laetitia nie wyraził woli zmiany doktryny moralnej i dyscypliny sakramentalnej Kościoła, wręcz przeciwnie - po wielokroć odwoływał się do wcześniejszych dokumentów Magisterium. Zatem adhortacja Amoris laetitia winna być interpretowana w duchu kontynuacji nauczania kościelnego.

2) Nie została dokonana zmiana w przepisach prawa kanonicznego odnośnie norm kodeksowych regulujących przystępowanie wiernych do Komunii św. Normy te nadal obowiązują.

3) Papież Franciszek nie unieważnił też kryteriów dopuszczania do sakramentów zawartych w adhortacji apostolskiej Familiaris consortio i późniejszych dokumentach Magisterium.

4) Adhortacja apostolska Amoris laetitia wprowadza kryterium dodatkowe dopuszczania do Komunii św., polegające na rozeznaniu duszpasterskim. Można je inaczej określić jako kryterium 
sumienia duszpasterza. Kryterium to powinno być interpretowane w zgodzie z doktryną moralną Kościoła. Oznacza to, że żaden z duszpasterzy dokonujących rozeznania nie może się uważać za autonomicznego decydenta o prawach moralnych, lecz sędziego dokonującego miłosiernej oceny.

5) Adhortacja papieża Franciszka może wprowadzać zamieszanie ze względu na małą precyzję języka, jeśli jednak zostanie zinterpretowana $\mathrm{z}$ uwzględnieniem hermeneutyki kontynuacji i ciągłości Magisterium, będzie dokumentem bardzo pomocnym dla duszpasterzy, ale także bardzo wymagającym.

6) Prawidłowo zinterpretowana adhortacja apostolska Amoris laetitia pozostaje spójna z dotychczasowym nauczaniem Kościoła i jego dyscypliną sakramentalną. Oznacza to, że decyzja o dopuszczeniu do Komunii św. wiernych pozostających w tzw. małżeńskich sytuacjach nieregularnych musi być oparta na obiektywnie istniejących normach prawa moralnego i kanonicznego.

SUMMARY

\section{Admission to Holy Communion of couples without sacramental marriage: a norm or a subjective assessment?}

The aim of this article is to analyze the current legal situation and regulations concerning the full participation of the faithful in the sacrament of the Eucharist in the light of the apostolic exhortation Amoris laetitia of Pope Francis. The question is whether the Pope has changed the criteria for the admission of the Communion for to the faithful living in nonsacramental marriages? If so, does this amendment lead to the objective norms being rejected in favor of subjective judgment? In attempting to find 
answers to the above questions, the author first presents the current legal status and the ecclesiastical discipline in this area. Next, he points out those passages of the papal document in question that have given interpretative controversies and to present the most significant responses to them. Keywords: Francis, Amoris laetitia, non-marriage couples, Eucharist

Piotr Steczkowski, Dopuszczenie do Komunii Świętej osób żyjących po małżeńsku bez małżeństwa - norma czy subiektywna ocena?, w: Dyskusje nad „Amoris laetitia”, red. Piotr Kroczek, Kraków 2017, s. 69-93 (Annales Canonici Monographiae, 6).

DOI: http://dx.doi.org/10.15633/9788374386463.05 